\title{
Anti-aging Effects of Diospyros kaki Thunb. Extracts in UVA-irradiated Epidermal Keratinocytes
}

\author{
Joong Hyun Shim ${ }^{1 *}$, Sunyoung Park ${ }^{2}$ \\ ${ }^{1}$ Faculty of Cosmetics and Beauty Biotechnology, Semyung University, Jecheon-si, Chungcheongbuk-do, Korea \\ ${ }^{2}$ Department of Oriental Medicine, Semyung University, Jecheon-si, Chungcheongbuk-do, Korea
}

\author{
"Corresponding author: Joong Hyun Shim, \\ Faculty of Cosmetics and Beauty \\ Biotechnology, Semyung University, 65 \\ Semyung-ro, Jecheon-si, Chungcheongbuk-do \\ 27136, Korea \\ Tel.: +82436491615 \\ Fax: +82436491730 \\ Email: jhshim@semyung.ac.kr
}

Received January 17, 2017

Revised April 19, 2017

Accepted April 25, 2017

Published June 30, 2017

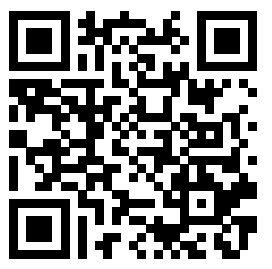

\begin{abstract}
Purpose: This study aimed to investigate the anti-aging effects of Diospyros kaki Thunb. (DKT) leaf extracts on normal human epidermal keratinocytes (NHEKs). Methods: To investigate the anti-oxidative effects of DKT leaf extracts on NHEKs, we measured radical-scavenging activity using the 1,1-diphenyl-2-picrylhydrazyl (DPPH) method. Furthermore, to elucidate the expression of genes and proteins related to skin hydration, we performed a cell viability assay and hyaluronic acid (HA)-enzyme-linked immunosorbent assay (ELISA) and also measured mRNA expression. Results: We elucidated the effects of DKT leaf extracts on aquaporin 3 (AQP3)/hyaluronan synthase 2 (HAS2)/keratin 1 (KRT1)/keratin 10 (KRT10) mRNA expression and HA production. Real-time polymerase chain reaction (real-time PCR) showed that DKT leaf extracts increased mRNA levels of AQP3/HAS2/KRT1/KRT10, and the HA-ELISA revealed that DKT leaf extracts increased HA production in NHEKs. Conclusion: The results are indicative of the anti-aging effects of DKT leaf extracts; therefore, DKT leaf extracts may be a potent cosmetic ingredient for anti-aging and skin moisturizing. Based on these findings, we anticipate further research on DKT leaf extracts for mechanisms with a view to developing not only cosmetics but also medicines or healthcare food.
\end{abstract}

Keywords: Diospyros kaki Thunb. leaf, Anti-aging, Hyaluronic acid, AQP3, HAS2

\section{Introduction}

인체의 장기 중 최외각에 위치한 피부는 우리 몸의 항상성을 저해 하는 외부 인자의 침입을 막아주는 일차적인 보호기관이다. 피부는 외부의 화학적, 물리적, 생물학적 장벽기능을 수행하고 있으나 다양 한 환경적 요인과 접촉하고 있기 때문에 손상을 받기 쉽다(Lee et al., 2007; Yoon et al., 2013). 피부는 외부의 다양한 환경요인에 항시 접 촉하고 있어 산화적 스트레스에 노출되어 있고, 특히 잦은 자외선 노 출은 피부에 활성산소종(reactive oxygen species)을 생성하게 하 고, 이는 피부의 항산화 시스템을 붕괴시킴과 동시에 세포손상을 야 기함으로써 피부의 주름, 탄력저하, 색소침착 등과 같은 피부노화를 유발한다(Kim et al., 2011).

외부 스트레스 중 자외선(ultraviolet, UV)은 파장의 길이에 따라 UVA (장파장, 320-400 nm), UVB (중파장, 290-320 nm), UVC (단 파장, 200-290 nm)로 구분된다(Kim et al., 2011; Lee et al., 2007).
특히, UVA와 UVB는 DNA 손상과 세포사멸 수용체 활성화, 그리 고 활성산소종을 생성시켜 세포사멸을 유도하고(Assefa et al., 2005), UVA와 UVB에 의해 촉진된 활성산소종의 생산은 직접적 혹은 간접적으로 염증반응, 광감작, 암화 등을 유도한다(Bickers \& Athar, 2006).

인간각질형성세포는 자외선에 의해 $\mathrm{AQP} 3$ 의 발현이 감소되어 피 부건조를 유발한다고 알려져 있다(Cao et al., 2008). AQPs는 소수성 을 띤 세포막 내재 단백질(small hydrophobic integral membrane proteins)로, 세포 외부의 수분을 특이적으로 세포 내로 수송하는 단 백질이다(Hara-Chikuma \& Verkman, 2008; Sougrat et al., 2002). 각질형성세포는 세포막에 $\mathrm{AQP} 3$ 를 발현하고 있고, $A Q P 3$ 낙 아웃 마우스는 피부보호막 손상, 피부보습, 상처치유능 저하 등의 피 부결함을 보인다는 보고가 있다(Sougrat et al., 2002). 또한 보습에 관여하는 히알루론산(hyaluronic acid, HA)을 생성하는 효소인 HAS2 역시 자외선에 의해 감소된다는 보고가 있다(Hašová et al., 2011). 


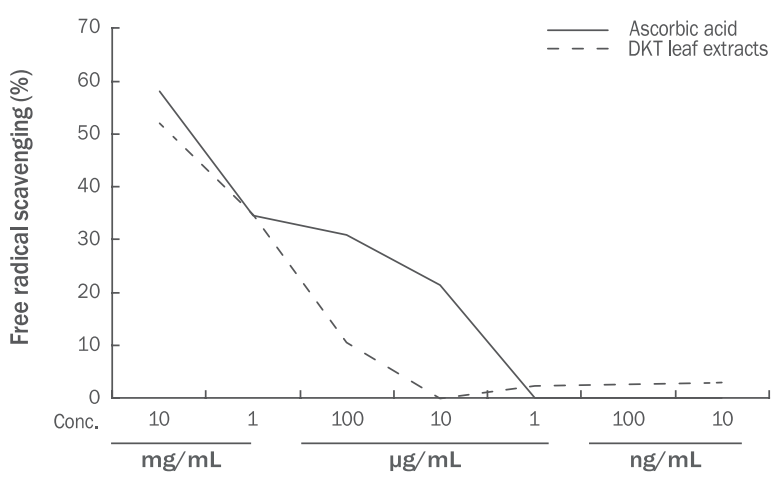

Figure 1. Free radical-scavenging effects of DKT leaf extracts. The anti-oxidant effects of DKT leaf extracts were measured using the DPPH assay at the indicated concentrations. DKT leaf extracts exhibited free radical-scavenging effects similar to those exhibited by the positive control (ascorbic acid) at 10 and $1 \mathrm{mg} / \mathrm{mL}$. DKT, Diospyros kaki Thunb.; Conc., concentration; DPPH, 1,1-diphenyl2-picrylhydrazyl.

자외선에 의해 노화된 피부에 히알루론산을 처리하게 되면, 피부노화 증상과 피해를 감소시키는 역할을 한다. 또한 자외선은 표피 내 기저 층에 존재하는 각질형성세포를 과각질화시켜 표피의 노화를 유발하 는데, 기저층의 각질형성세포가 발현하는 keratin 5 (KRT5), keratin 14 (KRT14) 유전자의 발현을 감소시키고 filaggrin (FLG), loricrin $(\mathrm{LOR}), \mathrm{KRT1}, \mathrm{KRT1O}$ 등의 유전자 발현을 증가시킨다고 알려져 있다 (Eckert et al., 2005).

감나무(Diospyros kaki Thunb.)는 우리나라 전역에서 자라는 과 실나무로 그 잎은 감잎차의 원료로 사용되어 왔다. 감잎에는 플라보 노이드 배당체, 페놀류, 탄닌, 커큐민류 화합물, 다당체, 환원당, 유기 산, 엽록소 등이 함유되어 있고 비타민 C의 함량이 녹차보다 3.5-21배 가량 많이 함유하고 있다. 감잎에 함유된 탄닌은 고혈압, 항산화 효 과, 항암 및 돌연변이 억제효과, 간손상 방지 등의 효능이 있는 것으 로 알려져 있다(Joung et al., 1995; Kameda et al., 1987; Son \& Kim, 2011; Uchida et al., 1987).

그러나, 감잎 열수 추출물이 NHEKS에서 보습과 피부노화 개선 등 에 효능이 있는지에 대한 연구는 미흡한 실정이다. 본 연구에서는 감 잎 열수 추출물의 보습 효능과 관련되어 $A Q P 3$ 와 $H A S 2$ 유전자의 발현 에 미치는 영향을 확인해 보고, 자외선에 의해 감소된 NHEKs의 히알 루론산 생산 능력이 감잎 열수 추출물에 의해 증가되는지 입증하고자 한다. 또한 자외선에 의해 과각질화가 유도된 상태에서 감잎 열수 추 출물의 과각질화를 억제하는 효능이 있는지 확인하고자 한다. 이를 통 해 향후 감잎의 항노화 화장품 소재로서의 가능성을 평가하고자 한다.

\section{Methods}

\section{1. 감잎 열수 추출법}

감잎(Diospyros kaki Thunb. leaf)은 서울 경동시장(Korea)에서 구입하였고, 증류수 $2,000 \mathrm{~mL}$ 와 감잎 $200 \mathrm{~g}$ 을 round flask에 넣 고 $100^{\circ} \mathrm{C}$ 에서 $2 \mathrm{~h}$ 동안 가열 추출한 후, 진공회전 농축기(EYELA N-2100; Tokyo Rikakikai, Japan)로 감압 농축하였다. 이후 동결 건 조기로 건조하여 얻은 $38.90 \mathrm{~g}$ (건조중량 대비 수득율: $19.45 \%$ )의 분 말을 실험에 사용하였다.

\section{2. 세포배양}

NHEKs와 세포배양을 위한 배지인 KGM-gold bulletKit은 Lonza (Switzerland)에서 구입하여 사용하였다. $\mathrm{NHEKs}$ 는 $37^{\circ} \mathrm{C}, 5 \% \mathrm{CO}_{2}$, 습도 $100 \%$ 의 세포배양기에서 배양하였다.

\section{DPPH 라디컬 소거능 분석}

$\mathrm{DPPH}$ 라디컬(Sigma-Aldrich, USA) 소거능 분석을 위해 DPPH 를 methanol:water (3:2)에 $0.1 \mathrm{mM}$ 로 녹여 사용하였다. $\mathrm{DPPH}$ 용 액 $500 \mu \mathrm{L}$ 에 시료 $50 \mu \mathrm{L}$ 를 넣고 실온에서 $20 \mathrm{~min}$ 동안 반응시킨 후 microplate spectrophotometer (Epoch; BioTek Instruments, $\mathrm{USA}$ 로 $517 \mathrm{~nm}$ 의 파장에서 흡광도를 측정하였다. 양성대조군으로 는 ascorbic acid (Sigma-Aldrich)를 사용하였다. DPPH 라디컬 소 거능은 시료무첨가군과 시료첨가군 사이의 흡광도 차이를 백분율로 나타내었다.

$\mathrm{DPPH}$ 라디컬 소거능 $(\%)=100-\{$ (시료첨가군의 흡광도/시료무첨가 군의 흡광도 $) \times 100$ \}

\section{4. 자외선 조사}

UVA 조사로 인한 NHEKs의 노화를 확인하기 위해서 하기와 같은 조건으로 UVA를 처리하였다. NHEKs가 배양되고 있는 $35 \mathrm{~mm}$ 배 양접시에 Dulbecco's Modified Eagle's Medium (DMEM, without phenol red; Welgene, Korea)을 접종한 후, 자외선 조사기(BioLink; Vilber Lourmat, Germany)를 사용하여 $3 \mathrm{~J} / \mathrm{cm}^{2}$ 의 UVA를 조 사하였다.

\section{5. 세포 생존율 분석}

세포 생존율은 cell counting kit-8 (CCK-8; DoGenBio, Korea) 분 석법을 이용하였다. NHEKs $\left(3 \times 10^{3}\right.$ cells/well)를 배양접시에 접종한 후 감잎 추출물을 농도 별로 $24 \mathrm{~h}$ 처리하고 $\mathrm{OCK}-8$ 시약을 DMEM에 $1 / 10$ 로 희석하여 첨가한 후 $1 \mathrm{~h}$ 동안 세포배양기에서 배양하였다. 배 양액은 $450 \mathrm{~nm}$ 에서 흡광도를 측정하였으며, 세포를 배양하지 않은 배지만 넣은 대조군의 흡광도로 보정하여 세포 생존율을 산출하였다. 

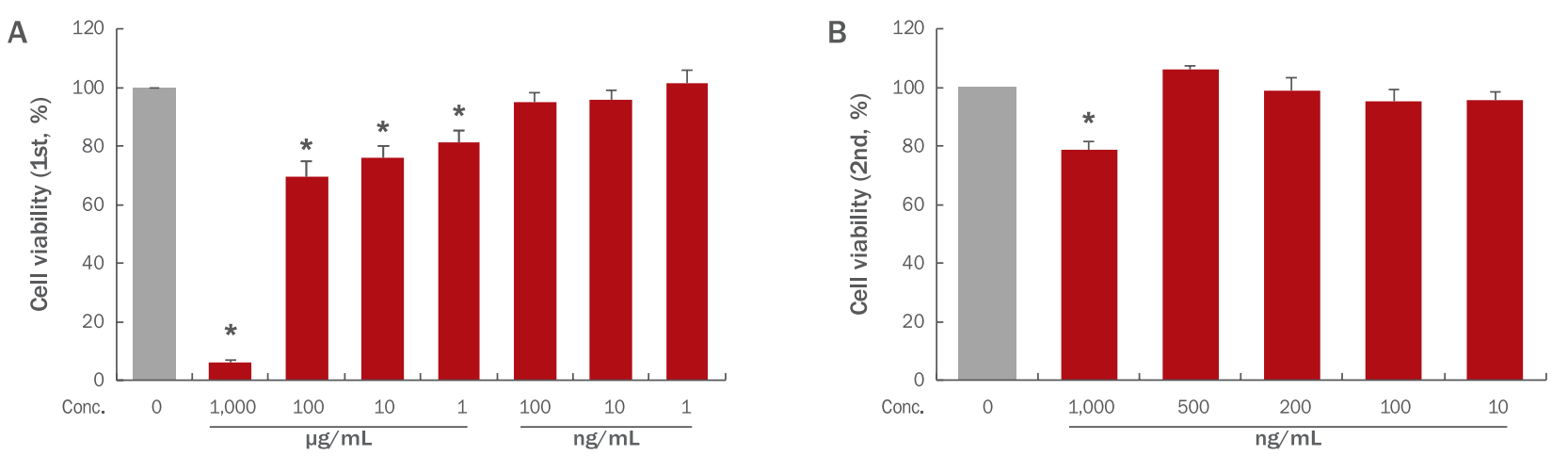

Figure 2. Cytotoxicity of DKT leaf extracts in NHEKs.

NHEKs $\left(3 \times 10^{3}\right.$ cells/well) were seeded in 96-well plates and treated with DKT leaf extracts for $24 \mathrm{~h}$. Cell viability was measured using CCK-8 solution. The first CCK-8 assay showed that cell survival rate at $1 \mu \mathrm{g} / \mathrm{mL}$ of DKT leaf extracts was significantly lower than that for the control group (A). The survival rate at $500 \mathrm{ng} / \mathrm{mL}$ of DKT leaf extracts was similar to that for the control group (B). Results are presented as $\mathrm{M} \pm$ S.D. of the percentage of control optical density in triplicates. ${ }^{*} p<0.05$ compared with control group. Conc., concentration; DKT, Diospyros kaki Thunb.; NHEKs, normal human epidermal keratinocytes; CCK-8, cell counting kit-8; Control group, the group untreated with DKT leaf extracts; M \pm S.D., means \pm standard deviations.

A

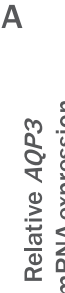

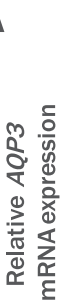

UVA $\left(3 \mathrm{~J} / \mathrm{cm}^{2}\right)$
DKT leaf extracts
$(\mathrm{ng} / \mathrm{mL})$

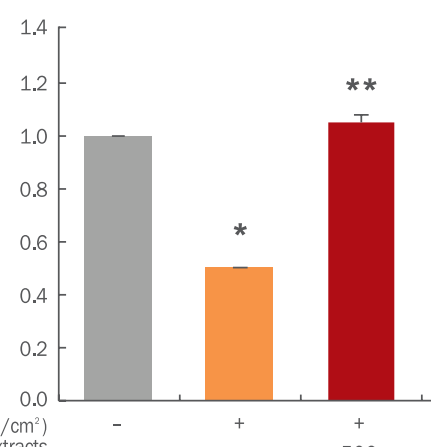

500

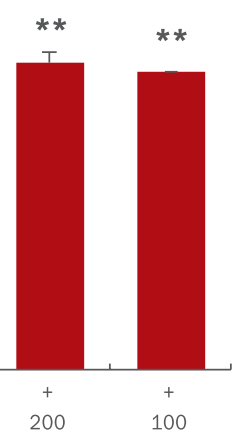

$200 \quad 100$

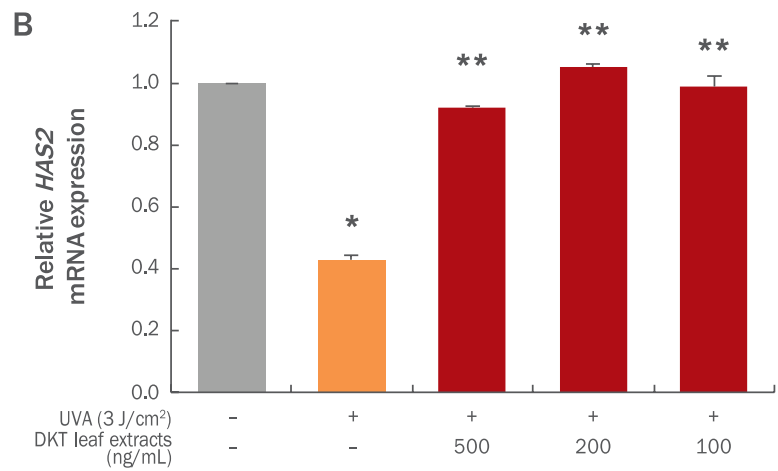

Figure 3. Characterization of DKT leaf extracts treatment on UVA-irradiated NHEKs.

The mRNA expression levels of the epidermal keratinocyte markers such as AQP3 (A) and HAS2 (B) were analyzed by real-time PCR. The AQP3 gene expression was 2.3 times and the HAS2 gene expression was 2.4 times higher than UVA-treated condition. Values are given as $\mathrm{M} \pm$ S.D. of three independent experiments. ${ }^{*} p<0.01$ compared with control group, ${ }^{* *} p<0.01$ compared with UVAirradiated group. DKT, Diospyros kaki Thunb.; AQP3, aquaporin 3; HAS2, hyaluronan synthase 2; UVA, ultraviolet A; NHEKs, normal human epidermal keratinocytes; Real-time PCR, real-time polymerase chain reaction; $\mathrm{M} \pm \mathrm{S}$.D., means \pm standard deviations; Control group, the group untreated with UVA and DKT leaf extracts.

Table 1. Gene symbol, name, and assay ID number in real-time PCR analysis

\begin{tabular}{lll}
\hline Gene symbol & Gene name & Assay ID \\
AQP3 & Aquaporin 3 & Hs01105469_g1 \\
HAS2 & Hyaluronan synthase 2 & Hs00193435_m1 \\
FLG & Filaggrin & Hs00856927_g1 \\
LOR & Loricrin & Hs01894962_s1 \\
KRT1 & Keratin 1 & Hs01549614_g1 \\
KRT10 & Keratin 10 & Hs01043114_g1 \\
GAPDH & Glyceraldehyde-3-phosphate dehydrogenase & 43333764F \\
\hline
\end{tabular}

Real-time PCR, real-time polymerase chain reaction. 


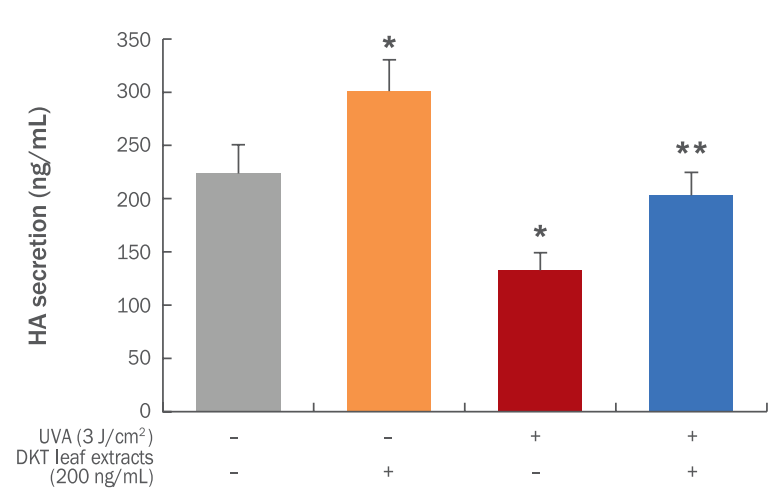

Figure 4. Effects of DKT leaf extracts on HA synthesis in NHEKs. NHEKs were seeded in $35 \mathrm{~mm}$ culture dishes and treated with DKT leaf extracts for $48 \mathrm{~h}$. The medium used for each condition was collected and analyzed using HA-ELISA. HA production, which was decreased by $40 \%$ by UVA irradiation, increased by $53 \%$ upon treatment with DKT leaf extracts. Values are given as $\mathrm{M} \pm$ S.D. of three independent experiments. ${ }^{*} p<0.05$ compared with control group, ${ }^{* *} p<0.05$ compared with UVA-irradiated group. HA, hyaluronic acid; UVA, ultraviolet A; DKT, Diospyros kaki Thunb.; NHEKs, normal human epidermal keratinocytes; ELISA, enzyme-linked immunosorbent assay; $\mathrm{M} \pm S$.D., means \pm standard deviations; Control group, the group untreated with UVA and DKT leaf extracts.

\section{RNA 추출 및 실시간 유전자 중합효소 연쇄반응(Real-time PCR)}

TRIzol reagent (Invitrogen ${ }^{\mathrm{TM}}$, Thermo Fisher Scientific, USA)를 사용하여 RNA를 추출하였다. ReverTra Ace ${ }^{\circledR}$ reverse transcription kit (Toyobo, Japan)를 이용하여 RNA로부터 cDNA 를 합성하였으며, NHEKs 표지인자 발현양상을 비교하기 위하 여 real-time PCR (StepOnePlus Real-Time PCR System; Thermo Fisher Scientific)을 진행하였다. 실험에 사용된 특정 TaqMan ${ }^{\circledR}$ Gene Expression Assay (Thermo Fisher Scientific)는 Table 1과 같다.

\section{7. 히알루론산-효소결합 면역흡착법(HA-ELISA)}

감잎 열수 추출물에 의한 히알루론산 생성 정도를 알아보기 위하 여 NHEKs를 $24 \mathrm{~h}$ 동안 $37^{\circ} \mathrm{C} \mathrm{CO}$ 배양기에서 배양한 후, $3 \mathrm{~J} / \mathrm{cm}^{2}$ 의 $\mathrm{UVA}$ 를 조사하였다. 자외선 조사 후 감잎 열수 추출물을 첨가하여 세 포배양기에서 $48 \mathrm{~h}$ 동안 배양하였다. 배양액 내의 히알루론산 단백질 의 양은 Hyaluronic Acid (HA) Test Kit (Corgenix, USA)를 이용하여 측정하였다.

\section{8. 통계분석}

본 실험에서의 통계처리는 Student's t-test법을 이용해 유의 수 준 0.05 ( $p<0.05)$ 로 하여 검정하였다.

\section{Results and Discussion}

\section{1. 감잎 열수 추출물의 DPPH 라디컬 소거능}

활성산소종의 과도한 생성은 노화나 암 등의 질환을 유발하며, 활 성산소종은 피부 광노화에 있어 중요한 역할을 하는 것으로 알려져 있다(Pryor, 1982). 항산화제의 라디컬 소거능을 평가하는데 일반적 으로 사용되는 $\mathrm{DPPH}$ 는 비교적 안정한 라디컬로서 전자를 공여 받 게 되면 자체의 자색이 엷어진다. 본 연구에서 감잎 열수 추출물을 10 $\mathrm{mg} / \mathrm{mL}$ 에서 $10 \mathrm{ng} / \mathrm{mL}$ 의 농도로 연속 희석하여 라디컬 소거능을 측 정한 결과, 농도 의존적으로 $\mathrm{DPPH}$ 라디컬 소거능이 증가하였으며, 특별히 $10 \mathrm{mg} / \mathrm{mL}$ 과 $1 \mathrm{mg} / \mathrm{mL}$ 의 감잎 추출물 처리시 양성대조군으 로 사용한 ascorbic acid와 유사한 항산화 효과를 지님을 확인하였다 (Figure 1). 감잎은 플라보노이드 배당체, 페놀류, 탄닌, 커큐민류, 비타민 C 등과 같은 다양한 항산화 물질과 다당체, 환원당, 유기산, 엽록소 등이 함유되어 있는 소재로 다류 등으로 사용되는 식물로 알 려져 있다(Joung et al., 1995; Son \& Kim, 2011). 따라서, 본 연구 결과는 감잎에 함유된 풍부한 항산화 물질에 의해 항산화 효과가 나 타났다는 Lee (2014)의 보고와 일치하였다.

\section{NHEKs에서 감잎 열수 추출물의 농도별 생존율 분석}

$\mathrm{NHEKs}$ 에 대한 감잎 열수 추출물의 세포독성을 확인하기 위하 여 CCK-8 assay를 수행하였다. 대조군은 시료를 처리하지 않았고 감잎 열수 추출물은 $1,10,100 \mathrm{ng} / \mathrm{mL}, 1,10,100,1,000 \mu \mathrm{g} / \mathrm{mL}$ 의 농도 순으로 처리하여 세포 생존율을 측정하였다(Figure 2A). 감잎 열수 추출물을 $1 \mu \mathrm{g} / \mathrm{mL}$ 농도 이상 처리할 때 $\mathrm{NHEKs}$ 의 생존율이 유의성 있게 감소하여, 추가적으로 $1 \mu \mathrm{g} / \mathrm{mL}$ 과 $10 \mathrm{ng} / \mathrm{mL}$ 사이의 농도 를 세분화하여 OCK-8 assay를 실시하였다(Figure 2B). $500 \mathrm{ng} / \mathrm{mL}$ 의 농도에서 $\mathrm{NHEKs}$ 의 생존율이 대조군과 유사함을 확인하여 본 실험에 서는 $500,200,100 \mathrm{ng} / \mathrm{mL}$ 의 감잎 열수 추출물을 처리하여 추가실험 을 수행하였다.

\section{3. 자외선 조사와 감잎 열수 추출물 처리에 따른 NHEKs의 mRNA 발현}

$\mathrm{NHEKS}$ 에 UVA $\left(3 \mathrm{~J} / \mathrm{cm}^{2}\right)$ 를 조사한 후, 감잎 열수 추출물을 24 $\mathrm{h}$ 처리하여 $\mathrm{NHEKs}$ 가 발현하는 보습인자인 $A Q P 3$ 와 $H A S 2$ 의 발현 양을 real-time PCR법을 통하여 확인하였다. $A Q P 3$ 와 $H A S 2$ 는 인 간각질형성세포에서 발현되는 유전자로 보습에 관여하는 표지인 자로 알려져 있다(Park \& Shim, 2016). 자외선 조사에 의해 AQP3, $H A S 2$ 의 발현이 감소하였으나, $200 \mathrm{ng} / \mathrm{mL}$ 의 감잎 열수 추출물 처 리군에서 자외선 조사군 대비 $A Q P 3$ 의 발현이 2.3배(Figure $3 \mathrm{~A}$ ), $H A S 2$ 의 발현이 2.4배(Figure $3 \mathrm{~B}$ ) 증가하는 효과를 보였다. 세포 외 부의 수분을 세포 내로 수송하는 기능을 담당하는 AQP3과 히알루 론산을 생성하는 효소인 $\mathrm{HAS} 2$ 의 $\mathrm{mRNA}$ 발현을 증가시키는 결과 를 바탕으로, 감잎 열수 추출물이 피부보습에 긍정적인 기능이 있는 
A

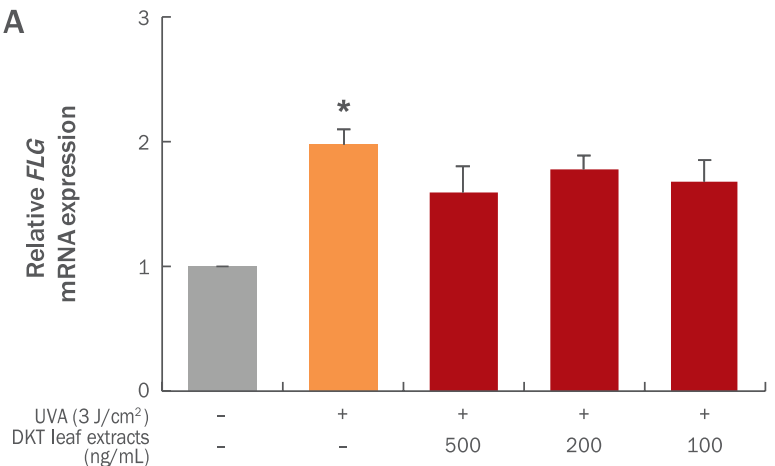

C

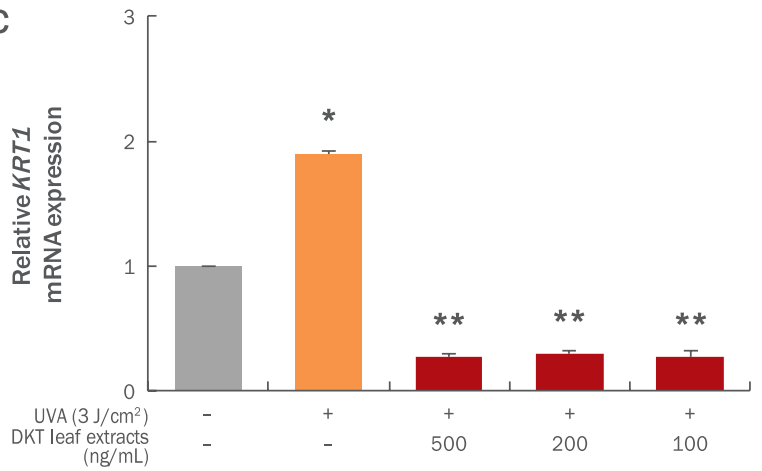

B

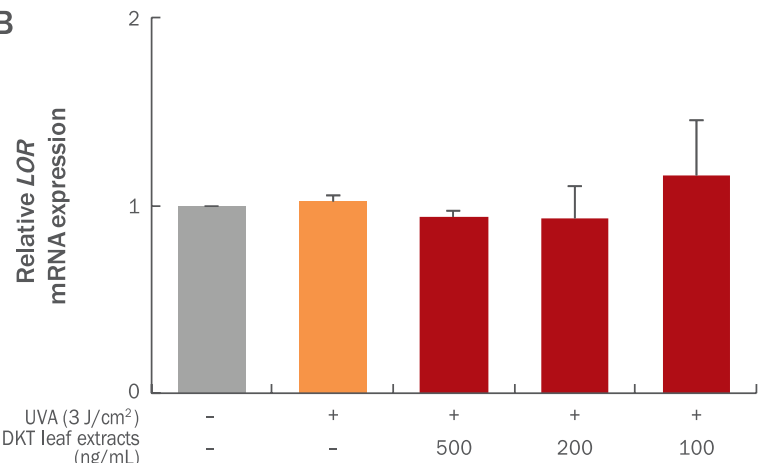

D

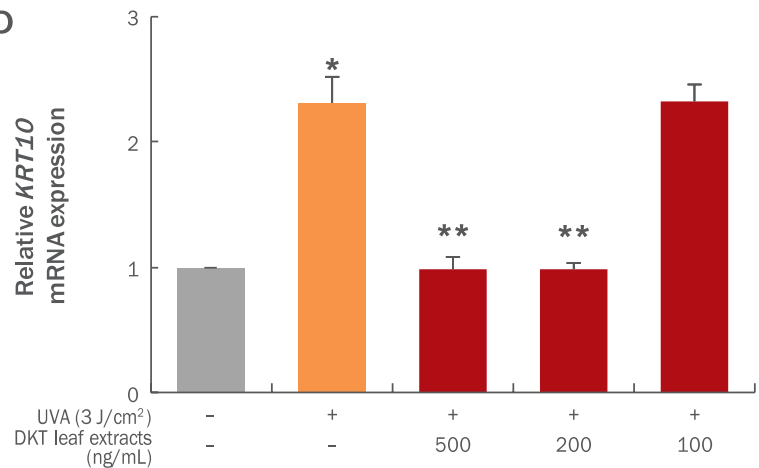

Figure 5. Differentiated marker expression of DKT leaf extracts treatment on UVA-irradiated NHEKs.

Real-time PCR analysis of the differentiated epidermal keratinocyte markers, FLG (A), LOR (B), KRT1 (C), and KRT1O (D). DKT leaf extracts decreased the expressions of KRT1 and KRT10, which were increased by UVA. The data are shown as M \pm S.D. of three independent experiments. " $p<0.05$ compared with control group, ${ }^{* *} p<0.05$ compared with UVA-irradiated group. FLG, filaggrin; LOR, loricrin; KRT1, keratin 1; KRT10, keratin 10; UVA, ultraviolet A; DKT, Diospyros kaki Thunb.; NHEKs, normal human epidermal keratinocytes; Real-time $\mathrm{PCR}$, real-time polymerase chain reaction; $\mathrm{M} \pm \mathrm{S}$.D., means \pm standard deviations; Control group, the group untreated with UVA and DKT leaf extracts.

것으로 사료된다(Hara-Chikuma \& Verkman, 2008; Hašová et al., 2011; Sougrat et al., 2002).

\section{4. 감잎 열수 추출물의 히알루론산 생성 촉진 효과}

HAS2는 인간각질형성세포에서 히알루론산을 생합성 하는데 중 요한 역할을 하는 효소로 알려져 있다(Karvinen et al., 2003; Kim et al., 2004). 감잎 열수 추출물을 처리하여 HAS2 mRNA의 발현량이 증가된 NHEKS에서 히알루론산 단백질의 생성 역시 증가되는지를 알아보기 위해 히알루론산에 대한 효소결합 면역흡착법을 사용하여 측정하였다(Figure 4). 실험결과, UVA 조사에 의해 $40 \%$ 가량 생성이 감소되었던 히알루론산이 감잎 열수 추출물 처리에 의해 자외선 조사 군 대비 $53 \%$ 가량 증가함을 확인하였다. 이 결과는 실시간 유전자 중 합효소 연쇄반응의 HAS2 $\mathrm{mRNA}$ 에 대한 실험 결과와 일관성이 있으 며, 감잎 열수 추출물은 HAS2 $\mathrm{mRNA}$ 의 발현뿐 아니라 유전자 발현 에 의한 산물인 히알루론산 단백질의 생성 역시 증가시킬 수 있음을 시사한다.

\section{5. 감잎 열수 추출물의 표피분화마커 발현에 대한 효과}

인간각질형성세포는 기저층에서 각질층으로 분화되면서 각질화되 어 탈락되는 각질턴오버를 거친다. 기저층의 각질형성세포가 유극층, 과립층, 각질층으로 분화가 되면서 KRT5, KRT14 등의 표지인자의 발현은 감소하고 FLG, LOR, KRT1, KRT10과 같은 단백질 발현은 증 가한다고 알려져 있다(Eckert et al., 2005). 따라서 기저층의 각질형 성세포 표지인자로 KRT5와 KRT14 등의 단백질이 표지인자로 사용 되고, 과립층 및 유극층의 각질형성세포는 FLG, LOR, KRT1, KRT10 등의 단백질이 표지인자로 활용된다. 표피층이 자외선과 같은 외인성 노화를 유도하는 스트레스를 받게 되면 각질형성세포의 분화가 촉진 되어 과각질화가 유도된다. 본 실험에서는 NHEKS에 UVA를 조사하 여 과각질화를 유도한 상태에서 감잎 열수 추출물을 처리했을 때, 분 화된 각질형성세포의 표지인자인 $F L G, L O R, K R T 1, K R T 10$ 의 발현 을 real-time PCR법으로 확인하였다. 위의 4 가지 표지인자 중 자외 선에 의해 $F L G, K R T 1, K R T 10$ 의 발현이 현저하게 증가하였고 $L O R$ 의 발현에는 큰 영향을 끼치지 않았다(Park \& Shim, 2016). $F L G$ (Figure $5 \mathrm{~A}$ )와 $L O R$ (Figure $5 \mathrm{~B}$ )은 감잎 열수 추출물에 의해 특이적인 발현의 차이는 보이지 않은 반면, $K R T 1$ 의 경우 감잎 열수 추출물 처 
리시 $K R T 1$ 의 발현이 자외선 처리군 대비 $85 \%$ 감소하고(Figure $5 \mathrm{C}$ ), $K R T 10$ 의 경우에는 $500 \mathrm{ng} / \mathrm{mL}$ 과 $200 \mathrm{ng} / \mathrm{mL}$ 의 농도에서 $58 \%$ 가량 감소함을 확인할 수 있다(Figure 5D). 이는 자외선이 각질형성세포의 과각질화를 유발하지만, 감잎 열수 추출물이 KRT1과 $K R T 10$ 의 발현 을 감소시켜 과도한 분화를 억제시킬 수 있음을 보여준다.

\section{Conclusion}

피부노화의 증상으로 각질층이 두꺼워지고 주름이 증가하고 염 증 등의 증상이 나타나게 된다. 자외선과 같은 외부환경에 의해 피부 에서는 활성산소종의 연쇄 반응이 야기되어 노화가 촉진되고 피부 질환이 발생하게 된다(Kim et al., 2011; Talwar et al., 1995). 또한 노 화는 성체 내 존재하는 구성세포의 감소, 혹은 기능저하에 의해 정상 적인 기능을 하는 조직으로의 재생, 기능을 하지 못하게 된다(Jones \& Rando, 2011; Kirkwood, 2005). 본 연구에서 감잎 열수 추출물을 $\mathrm{NHEKS}$ 에 처리할 적정 농도를 확인할 수 있었다. $500 \mathrm{ng} / \mathrm{mL}$ 이하 의 농도에서 세포의 생존율에 영향을 미치지 않음을 Figure 2 를 통해 확인하였다. $H A S 2$ 와 $A Q P 3$ 의 유전자 발현 측정과 히알루론산 단백 질 발현 측정에서 감잎 열수 추출물이 유의성 있게 자외선에 의해 감 소된 보습인자의 발현을 회복시키는 결과를 나타내었다(Figure 3, 4). 추가적으로 감잎 열수 추출물은 자외선 조사에 의해 증가된 $K R T 1$ 과 $K R T 10$ 의 유전자 발현을 낮춤으로 $\mathrm{NHEKs}$ 의 과각질화를 억제하는 능력이 있음을 확인할 수 있었다(Figure 5). 이는 감잎 열수 추출물이 피부 노화개선 후보물질로서의 가능성을 시사한다.

감잎 열수 추출물의 피부 보습 효과를 확인한 결과는 본 연구가 최 초로, 추후 화장품 및 피부미용에 실질적으로 응용이 될 수 있고 피부 노화를 개선할 수 있는 가능성을 보여주었다고 사료된다. 추가적으로 감잎 열수 추출물의 지표물질의 규명과, 열수 추출 이외의 다양한 용 매를 이용한 추출법으로 얻을 수 있는 추출물의 비교연구도 진행되어 야 한다. 향후 감잎 열수 추출물이 자외선에 의해 노화된 피부를 개선 하는 기전에 대한 추가연구와 본 추출물을 이용한 심도있는 임상연구 가 진행될 필요가 있을 것으로 보인다.

\section{Acknowledgements}

이 논문은 2016학년도 세명대학교 교내학술연구비 지원에 의해 수 행된 연구임.

\section{References}

Assefa Z, Van Laethem A, Garmyn M, Agostinis P. Ultraviolet radiation-induced apoptosis in keratinocytes: on the role of cytosolic factors. Biochimica et Biophysica Acta, 1755:
90-106, 2005.

Bickers DR, Athar M. Oxidative stress in the pathogenesis of skin disease. Journal of Investigative Dermatology, 126: 2565-2575, 2006.

Cao C, Wan S, Jiang Q, Amaral A, Lu S, Hu G, Bi Z, Kouttab N, Chu W, Wan Y. All-trans retinoic acid attenuates ultraviolet radiation-induced down-regulation of aquaporin-3 and water permeability in human keratinocytes. Journal of Cellular Physiology, 215: 506-516, 2008.

Eckert RL, Sturniolo MT, Broome AM, Ruse M, Rorke EA. Transglutaminase function in epidermis. Journal of Investigative Dermatology, 124: 481-492, 2005.

Hara-Chikuma M, Verkman AS. Roles of aquaporin-3 in the epidermis. Journal of Investigative Dermatology, 128: 2145-2151, 2008.

Hašová M, Crhák T, Safránková B, Dvořáková J, Muthný T, Velebný V, Kubala L. Hyaluronan minimizes effects of UV irradiation on human keratinocytes. Archives of Dermatological Research, 303: 277-284, 2011.

Jones DL, Rando TA. Emerging models and paradigms for stem cell ageing. Nature Cell Biology, 13: 506-512, 2011.

Joung SY, Lee SJ, Sung NJ, Jo JS, Kang SK. The chemical composition of persimmon (Diospyros kaki, Thumb) leaf tea. Journal of the Korean Society of Food Science and Nutrition, 24: 720-726, 1995.

Kameda K, Takaku T, Okuda H, Kimura Y, Okuda T, Hatano T, Agata I, Arichi S. Inhibitory effects of various flavonoids isolated from leaves of persimmon on angiotensin-converting enzyme activity. Journal of Natural Products, 50: 680-683, 1987.

Karvinen S, Pasonen-Seppänen S, Hyttinen JM, Pienimäki JP, Törrönen K, Jokela TA, Tammi MI, Tammi R. Keratinocyte growth factor stimulates migration and hyaluronan synthesis in the epidermis by activation of keratinocyte hyaluronan synthases 2 and 3. The Journal of Biological Chemistry, 278: 49495-49504, 2003.

Kim J, Lee CW, Kim EK, Lee SJ, Park NH, Kim HS, Kim HK, Char K, Jang YP, Kim JW. Inhibition effect of Gynura procumbens extract on UV-B-induced matrix-metalloproteinase expression in human dermal fibroblasts. Journal of Ethnopharmacology, 137: 427-433, 2011.

Kim S, Kang BY, Cho SY, Sung DS, Chang HK, Yeom MH, Kim DH, Sim YC, Lee YS. Compound K induces expression of hyaluronan synthase 2 gene in transformed human 
keratinocytes and increases hyaluronan in hairless mouse skin. Biochemical and Biophysical Research Communications, 316: 348-355, 2004.

Kirkwood TB. Understanding the odd science of aging. Cell, 120: 437-447, 2005.

Lee HY, Kim GJ, Kim YS, Lee SN, Lee SO. Skin science. Koonja Publishing, Paju, pp20-24, 2007.

Lee JH. Anti-oxidant and anti-inflammatory effects of Diospyros kaki Thumb leaves extracts. Asian Journal of Beauty and Cosmetology, 12: 719-724, 2014.

Park S, Shim JH. Anti-aging effect of Psoraleae fructus extract in UVA-irradiated HaCaT cells. Asian Journal of Beauty and Cosmetology, 14: 119-126, 2016.

Pryor WA. Free radicals in biology (V). Academic Press, Cambridge, pp270, 1982.

Son JY, Kim TO. Antioxidative and physiological activities of traditional Korean teas. Korean Journal of Food and Cookery Science, 27: 567-575, 2011.
Sougrat R, Morand M, Gondran C, Barré P, Gobin R, Bonté F, Dumas M, Verbavatz JM. Functional expression of AQP3 in human skin epidermis and reconstructed epidermis. Journal of Investigative Dermatology, 118: 678-685, 2002.

Talwar HS, Griffiths CE, Fisher GJ, Hamilton TA, Voorhees JJ. Reduced type I and type III procollagens in photodamaged adult human skin. Journal of Investigative Dermatology, 105: 285-290, 1995.

Uchida S, Edamatsu R, Hiramatsu M, Mori A, Nonaka G, Nishioka I, Niwa M, Ozaki M. Condensed tannins scavenge active oxygen free radicals. Medical Science Research, 15: 831-832, 1987.

Yoon Y, Bae S, An S, Choe YB, Ahn KJ, An IS. Effects of ultraviolet radiation on the skin and skin cell signaling pathways. Asian Journal of Beauty and Cosmetology, 11: 417-426, 2013. 


\section{국문초록}

\section{자외선 조사에 의해 노화된 인간각질형성세포에서 감잎 추출물의 항노화 효능}

심중현 ${ }^{1 *}$, 박선영 ${ }^{2}$

${ }^{1}$ 세명대학교 화장품·뷰티생명공학부, 충청북도 제천시, 한국

${ }^{2}$ 세명대학교 한의과대학, 충청북도 제천시, 한국

목적: 본 연구는 감잎 열수 추출물이 자외선에 의해 광노화가 유도된 인간각질형성세포의 항노화 효능을 확인하기 위하여 수행되 었다. 방법: 자외선으로 노화를 유도한 인간각질형성세포에서 감잎 열수 추출물의 항산화 효과를 확인하기 위해서 감잎 열수 추출 물의 라디컬 소거능을 분석하였다. 추가적으로 감잎 열수 추출물이 보습에 관련된 유전자 및 단백질의 발현에 미치는 영향을 확인 하기 위하여 농도별 세포 생존율, 유전자 발현 양상, 히알루론산 단백질의 발현 정도를 확인하였다. 결과: 감잎 열수 추출물의 항노 화 효능을 확인하기 위하여 aquaporin 3 (AQP3), hyaluronan synthase 2 (HAS2), keratin 1 (KRT1), keratin 10 (KRT10)의 유전 자 발현을 확인한 결과, 자외선 조사에 의해 감소한 $A Q P 3$ 와 $H A S 2$ 유전자의 발현이 감잎 열수 추출물에 의해 각각 2.3배, 2.4배 증 가하였다. 인간각질형성세포의 과각질화에 관여하는 $K R T 1$ 과 $K R T 10$ 의 유전자 발현은 감잎 열수 추출물에 의해 각각 $85 \%, 58 \%$ 감 소함을 확인하였다. 또한 히알루론산 단백질의 생성이 감잎 열수 추출물에 의해 $53 \%$ 가량 증가함을 확인하였다. 따라서 본 연구를 통해 감잎 열수 추출물의 보습 및 항노화 효능을 확인하였다. 결론: 본 연구를 통해 감잎 열수 추출물의 항노화 효능을 확인하였고, 향후 감잎 열수 추출물이 화장품 및 의약품과 건강식품의 개발에 활용할 수 있는 소재로서의 가능성을 확인하기 위하여 심도있는 기전연구가 필요할 것으로 생각된다.

핵심어: 감잎, 항노화, 히알루론산, $A Q P 3, H A S 2$

이 논문은 2016학년도 세명대학교 교내학술연구비 지원에 의해 수행된 연구임.

\section{참고문헌}

박선영, 심중현. 자외선 조사에 의해 노화된 $\mathrm{HaCaT}$ 세포에서 보골지 추출물의 항노화 효능. 아시안뷰티화장품학술지, 14 : 119-126, 2016.

손종연, 김태옥. 한국 전통차의 생리활성 및 항산화작용. 한국식품조리과학회지, 27: 567-575, 2011.

윤영민, 배승희, 안성관, 최용범, 안규중, 안인숙. 자외선(Ultraviolet)이 피부 및 피부세포 내 신호전달체계에 미치는 영향. 아

시안뷰티화장품학술지, 11: 417-426, 2013.

이정희. 감잎추출물의 항산화 및 항염증 효과. 아시안뷰티화장품학술지, 12: 719-724, 2014.

이혜영, 김귀정, 김영순, 이성내, 이성옥. 피부과학. 군자출판사, 파주, pp20-24, 2007.

정선영, 이수정, 성낙주, 조종수, 강신권. 감(Diospyros kaki, Thumb)잎차의 화학 성분. 한국식품영양과학회지, 24: 720$726,1995$. 


\section{中文摘要}

\section{柿蒂叶提取物对紫外线光老化的人角质形成细胞的抗衰老功效}

沁重鉉 ${ }^{*}$, 朴宣映 ${ }^{2}$

${ }^{1}$ 世明大学化妆品·美容生命工学科, 忠淸北道堤川市，韩国

${ }^{2}$ 世明大学韩医预科，忠清北道堤川市，韩国

目的: 探讨柿蒂叶热水提取物对紫外线光老化的人角质形成细胞的抗衰老功效。方法: 对紫外线诱导老化的人角质形成细 胞, 为确认柿蒂叶提取物的抗氧化功效，分析其提取物的自由基消除能力。此外，柿蒂叶热水提取物对保湿相关的遗传 因子和蛋白质表达的影响，确认不同浓度中的细胞生存率、基因表达及透明质酸的表达程度。结果：为确认柿蒂叶热水 提取物的抗衰老功效, 确认 aquaporin 3 (AQP3), hyaluronan synthase 2 (HAS2), keratin 1 (KRT1), keratin 10 (KRT10)等遗 传基因的表达，其结果显示: 柿蒂叶热水提取物的使用, AQP3和 HAS2的遗传基因的表达分别增加了2.3、2.4倍; 与人角 质形成细胞过度角化相关的遗传因子 KRT1和 KRT10的表达通过柿蒂叶热水提取物的使用，分别减少了 $85 \%$ 、 $58 \%$; 透明 质酸蛋白质也增加了 $53 \%$ 。以上研究了对柿蒂叶热水提取物的保湿及抗衰老功效。结论: 通过研究确认了柿蒂叶热水提取 物的抗衰老功效。将来判断柿蒂叶热水提取物在化妆品、医药品和健康食品的开发应用可行性仍需深度的机制研究。

关键词: 柿蒂叶，抗衰老，透明质酸， $A Q P 3, H A S 2$ 